\title{
The Effect of Variations in Gold and Oil Prices on BIST 100 Index
}

\author{
Dr. Ali Akgün \\ Selcuk University Faculty of Economics and Administrative Sciences \\ aakgun@selcuk.edu.tr \\ Assistant Professor Dr. İ. Erem Şahin \\ Selcuk University Faculty of Economics and Administrative Sciences \\ eremsahin@hotmail.com \\ Associate Professor Dr. Baki Yilmaz \\ Selcuk University Faculty of Economics and Administrative Sciences \\ bakiyilmaz_42@hotmail.com
}

Doi:10.5901/mjss.2013.v4n10p726

\begin{abstract}
It is commonly known that the factors that are affecting stock prices are macroeconomic variables, returns on alternative investment means, political and social stability, developments in other countries, risk preferences of domestic and foreign investors, information regarding companies and manipulations. Due to the effect of financial globalization and as local capital has transformed into an international quality, individual country economies are now more fragile against not only internal dynamics but external factors as well. Under these circumstances, the Borsa Istanbul is a stock market which has recently been popular for investors who carefully chase and direct their investments toward this spot. The present study, except the generally adopted economical factors, investigates the effect of variations in gold and oil prices on BIST 100 index econometrically. The reason for analyzing the effect of gold prices is that the global interest toward gold metal has increased overwhelmingly which caused major central banks of both developing and developed world countries increased their gold reserves. This tendency created a serious increased demand for gold which accordingly has led increased prices in the global market and affected other macro economical variables. The reason for analyzing oil prices is that fluctuation in oil prices affects economical factors both directly and indirectly. Whereas the BIST 100 index has positive relationship with oil prices; it has negative relationship with gold prices.
\end{abstract}

Keywords: Oil prices, gold prices, Johansen co-integration test, BIST 100 Index

\section{Introduction}

It is known that there is parallelism between economical development and advancement of capital markets. Especially capital markets that are one of the significant economy indicators has great importance regarding sourcing capital from the financial markets and also using savings of individual and corporate investors effectively and productively. It is known that stock markets have basic functions to supply the capital requirements of companies, to contribute extensional distribution of capital to all sects of the society, to reduce risks of investors and to supply information stream from companies to investors. Borsa Istanbul has been maintaining these functions for years increasingly.

Stock markets have gained importance and developed in last two decades especially in developing countries as a result of decreasing interest rates and inflation and of embracing more liberal economic policies by those countries (Karan, 2001, p.:41). Prices in stock markets emerge based on previous company performances, future expectations and economic condition. Stock prices reflect the investors' estimations regarding expected returns and future cash flows from a certain stock; and these estimations are affected from the general condition of the national economy and international economy. Since stocks are a risky investment means for investors, they require information about the factors affecting stock prices and their significance. The relationship between stock prices and macro economical factors affecting stock prices has been investigated by numerous researchers. Although there were different results found due to various 
periods, places and variables used in researches, existence of these relationships are common findings of these researches.

Due to its characteristics as an alternative investment to stocks and as a factor that can affect the stock prices, gold reserves the value of investments. While this characteristic heads off its other specifications, based on recent fluctuations in gold prices during the recent years, it is also recognized as a speculative investment mean as well. When we consider gold as a substitute choice for stocks, an increase in the price of either of them would end up as a price decrease in the other one (Albeni and Demir, 2005:7).

In modern economies, oil prices are also considered as an important variable which are affecting capital markets. The general opinion in economies is that capital equity markets would react against the change in oil price (Regnier: 2007). There are interaction between oil prices and capital markets due to direct or indirect economical effects of oil prices. As this interaction changes due to the oil dependency of a relevant country, it arises as a result of reflection of changes in economical parameters which are caused by the oil prices to the capital equity markets.

In the financial literature, determination of factors influencing stock prices has been a primary investigation area that constantly continues in terms of investors and portfolio managers. There are limited numbers of studies in which price variations of gold and oil are investigated. The purpose of this study is to determine effect of gold and oil price variations over BIST 100 index. To that end, first the literature search will be summarized and then the econometric method will be included. The analysis findings will eventually revealed and discussed.

\section{The Literature Search}

Studies considering factors that are determinants of stock prices have been primarily focused by researches in the financial literature. Especially, according to expanding globalization and increasing effectiveness of financial liberalization in the latest period, it was observed that the factors affecting the stock prices have been diversified. It was also observed that several factors that once affecting stock prices indirectly before, are now affecting the stock prices directly in our contemporary period. There are limited numbers of studies considering the effects of gold and oil prices which are determined in the international markets on stock markets. However, these factors have been considered together with other factors in previous several studies. Table 1 exhibits several studies regarding effects of gold and oil prices on stock markets and their results.

\begin{tabular}{|c|c|c|c|c|}
\hline Researcher & Country & Methodology & Period & Result \\
\hline $\begin{array}{l}\text { Sadorsky } \\
(1999)\end{array}$ & USA & VAR & $\begin{array}{l}\text { January } 1947- \\
\quad \text { April } 1996\end{array}$ & $\begin{array}{l}\text { It was presented that oil prices changes play significant role } \\
\text { in explaining the changes in stock prices; and that there is } \\
\text { positive relationship between them. }\end{array}$ \\
\hline $\begin{array}{l}\text { Faff and } \\
\text { Brailsford } \\
(1999)\end{array}$ & Australia & VAR & $1983-1996$ & $\begin{array}{l}\text { IT was revealed that there is significant and positive } \\
\text { relationship between oil prices and oil; gas industry and } \\
\text { derivative product industries. A significant and positive } \\
\text { relationship was observed between paper and packaging; } \\
\text { and significant and negative relationship was found between } \\
\text { transportation and banking industries. }\end{array}$ \\
\hline $\begin{array}{l}\text { Sadorsky } \\
(2001)\end{array}$ & Canada & VAR & $\begin{array}{c}\text { April } 1983 \text { - April } \\
1999\end{array}$ & $\begin{array}{l}\text { The increase in oil prices causes increase in stock prices in } \\
\text { oil and gas sectors. }\end{array}$ \\
\hline $\begin{array}{l}\text { El-Sharif et al. } \\
\qquad(2005)\end{array}$ & GB & $\begin{array}{l}\text { Multiple factor } \\
\text { analysis }\end{array}$ & $\begin{array}{c}1^{\text {st }} \text { January } 1989- \\
30^{\text {th }} \text { June } 2001\end{array}$ & $\begin{array}{l}\text { It was reported that changes in oil prices cause increase on } \\
\text { returns on the stock prices in oil and gas industries in Great } \\
\text { Britain. }\end{array}$ \\
\hline $\begin{array}{l}\text { Tully and } \\
\text { Lucey } \\
(2007)\end{array}$ & USA & ARCH-GARCH & 1983-2003 & $\begin{array}{l}\text { In the periods in which gold price increase, returns on stock } \\
\text { market decreases. }\end{array}$ \\
\hline $\begin{array}{l}\text { Henriques and } \\
\text { Sadorsky } \\
\text { (2008), }\end{array}$ & Canada & VAR & $\begin{array}{l}3^{\text {rd }} \text { January } 2001 \\
\text { and } \\
30^{\text {th }} \text { May } 2007\end{array}$ & $\begin{array}{l}\text { In the stock prices of the alternative energy businesses, } \\
\text { changes in technology stocks are more effective instead of } \\
\text { oil prices. }\end{array}$ \\
\hline $\begin{array}{l}\text { Park and Ratti } \\
(2008)\end{array}$ & USA & VAR & $\begin{array}{l}\text { January } 1986- \\
\text { December } 2005 \\
\end{array}$ & $\begin{array}{l}\text { Shocks in oil prices have significant effects on return on } \\
\text { stocks in the same month or within one-month period. }\end{array}$ \\
\hline $\begin{array}{l}\text { Soytaş and } \\
\text { Oran (2008) }\end{array}$ & Turkey & & $\begin{array}{l}2^{\text {nd }} \text { May } 2003-1^{\text {st }} \\
\text { March } 2007\end{array}$ & $\begin{array}{l}\text { There is no any expected effects in oil prices or in currency } \\
\text { rates. }\end{array}$ \\
\hline Chen (2009) & USA & Time series & $\begin{array}{l}\text { January.1957- } \\
\text { May.2009 }\end{array}$ & $\begin{array}{l}\text { High oil prices increases the possibility to transition from the } \\
\text { bull market into the bear market. }\end{array}$ \\
\hline
\end{tabular}




\begin{tabular}{|l|c|c|c|l|}
\hline $\begin{array}{l}\text { Nandha and } \\
\text { Singh (2011) }\end{array}$ & China & GMM & $\begin{array}{c}\text { May 1994 - } \\
\text { October 2009 }\end{array}$ & $\begin{array}{l}\text { The China stock market is affected by the oil prices in a } \\
\text { positive way. }\end{array}$ \\
\hline
\end{tabular}

Table 1. Studies presenting effects of gold and oil prices on stock prices.

\section{Data and Econometric Method}

In our study that is designated to reveal the relationship between changes in gold and oil prices and the BIST 100 index, logarithmic conversions of monthly data obtained from the R.T. Central Bank Electronic Data Distribution System (EVDS) and from the Energy Information Administration regarding the period of 2000:01-2013:04 were used.

\begin{tabular}{|c|c|c|c|c|c|c|}
\hline Variable & Description & $\begin{array}{c}\text { Number of } \\
\text { Observation }\end{array}$ & Average & $\begin{array}{c}\text { Standard } \\
\text { deviation }\end{array}$ & Minimum & Maximum \\
\hline BIST & $\begin{array}{c}\text { Borsa Istanbul 100 } \\
\text { Index }\end{array}$ & 160 & 35374.07 & 20823.54 & 8392.240 & 84291.11 \\
\hline GLD & Gold Prices & 160 & 766.4958 & 485.2 & 258.87 & 1778.82 \\
\hline BRENT & Brent Oil Prices & 160 & 62.58656 & 32.79806 & 18.710 & 132.720 \\
\hline
\end{tabular}

Table 2. Descriptive statistics about the applied variables

To investigate this relationship, initially stationary of the population was probed through Expanded Dickey Fuller (ADF), Phillips-Perron (PP) and Kwiatkowski-Phillips-Schmidt-Shin (KPSS) tests. Following testing the stationary of population, Johansen Co-integration Test was applied to determine whether they were co-integrated.

\section{Findings}

To obtain significant results in the analysis of time series in terms of econometrics and to overcome spurious regression, stationary tests were conducted for the time series in the first place. In this scope, statistical values were calculated for fixed models and for models with fixed trend through ADF, PP and KPSS unit root tests; and the results were exhibited in Table 3 and Table 4.

\begin{tabular}{|c|c|c|c|c|c|c|}
\hline & \multicolumn{2}{|c|}{ ADF } & \multicolumn{2}{|c|}{ PP } & \multicolumn{2}{|c|}{ KPSS } \\
\hline & t-statistics & $\begin{array}{l}\text { Critical } \\
\text { Values }\end{array}$ & t-statistics & $\begin{array}{l}\text { Critical } \\
\text { Values }\end{array}$ & $\begin{array}{c}\mathrm{LM} \\
\text { statistics }\end{array}$ & $\begin{array}{l}\text { Critical } \\
\text { Values }\end{array}$ \\
\hline \multirow{3}{*}{ BIST } & \multirow{3}{*}{-0.255393} & -3.472259 & \multirow{3}{*}{-0.317469} & -3.471719 & \multirow{3}{*}{1.368411} & 0.7390 \\
\hline & & -2.879846 & & -2.879610 & & 0.4630 \\
\hline & & -2.576610 & & -2.576484 & & 0.3470 \\
\hline \multirow{3}{*}{ GLD } & \multirow{3}{*}{-0.156444} & -3.471719 & \multirow{3}{*}{-0.162461} & -3.471719 & \multirow{3}{*}{1.528576} & 0.7390 \\
\hline & & -2.879610 & & -2.879610 & & 0.4630 \\
\hline & & -2.576484 & & -2.576484 & & 0.3470 \\
\hline \multirow{3}{*}{ BRENT } & \multirow{3}{*}{-1.262040} & -3.471987 & \multirow{3}{*}{-1.289976} & -3.471719 & \multirow{3}{*}{1.391644} & 0.7390 \\
\hline & & -2.879727 & & -2.879610 & & 0.4630 \\
\hline & & -2.576546 & & -2.576484 & & 0.3470 \\
\hline \multirow{3}{*}{$\Delta \mathrm{BIST}$} & \multirow{3}{*}{-11.0534} & -3.471987 & \multirow{3}{*}{-11.02441} & -3.471987 & \multirow{3}{*}{0.134149} & 0.7390 \\
\hline & & -2.879727 & & -2.879727 & & 0.4630 \\
\hline & & -2.576546 & & -2.576546 & & 0.3470 \\
\hline \multirow{3}{*}{$\Delta \mathrm{GLD}$} & \multirow{3}{*}{-11.69725} & -3.471987 & \multirow{3}{*}{-11.68163} & -3.471987 & \multirow{3}{*}{0.135646} & 0.7390 \\
\hline & & -2.879727 & & -2.879727 & & 0.4630 \\
\hline & & -2.576546 & & -2.576546 & & 0.3470 \\
\hline \multirow{3}{*}{$\triangle$ BRENT } & \multirow{3}{*}{-10.31292} & -3.471987 & \multirow{3}{*}{-10.31985} & -3.471987 & \multirow{3}{*}{0.040540} & 0.7390 \\
\hline & & -2.879727 & & -2.879727 & & 0.4630 \\
\hline & & -2.576546 & & -2.576546 & & 0.3470 \\
\hline
\end{tabular}

Table 3. Unit Root Test Results (Fixed) 
For fixed effect models, ADF, PP and KPSS unit root tests show that series of BIST 100 index, gold prices and oil prices were not stationary, but in their first difference they all become stationary. Hence, t-statistic values calculated for the abstract values of the ADF and PP tests were less than the MacKinnon critical values. This finding means that the $\mathrm{H}_{0}$ hypothesis which assumes that series include unit roots is not refused. On the other hand, KPSS test results show that instead of $\mathrm{HO}$ hypothesis which assumes that series were stationary, its alternative hypothesis were true.

\begin{tabular}{|c|c|c|c|c|c|c|}
\hline & \multicolumn{2}{|c|}{ ADF } & \multicolumn{2}{|c|}{ PP } & \multicolumn{2}{|c|}{ KPSS } \\
\hline & t-statistics & $\begin{array}{l}\text { Critical } \\
\text { Values }\end{array}$ & t-statistics & $\begin{array}{l}\text { Critical } \\
\text { Values }\end{array}$ & $\begin{array}{c}\mathrm{LM} \\
\text { statistics }\end{array}$ & $\begin{array}{l}\text { Critical } \\
\text { Values }\end{array}$ \\
\hline \multirow{3}{*}{ BIST } & \multirow{3}{*}{-2.623647} & -4.017185 & \multirow{3}{*}{-2.782262} & -4.016806 & \multirow{3}{*}{0.126427} & 0.2160 \\
\hline & & -3.438515 & & -3.438334 & & 0.1460 \\
\hline & & -3.143558 & & -3.143451 & & 0.1190 \\
\hline \multirow{3}{*}{ GLD } & \multirow{3}{*}{-2.928101} & -4.016806 & \multirow{3}{*}{-3.026679} & -4.016806 & \multirow{3}{*}{0.225126} & 0.2160 \\
\hline & & -3.438334 & & -3.438334 & & 0.1460 \\
\hline & & -3.143451 & & -3.143451 & & 0.1190 \\
\hline \multirow{3}{*}{ BRENT } & \multirow{3}{*}{-3.113423} & -4.017185 & \multirow{3}{*}{-2.925055} & -4.016806 & \multirow{3}{*}{0.121896} & 0.2160 \\
\hline & & -3.438515 & & -3.438334 & & 0.1460 \\
\hline & & -3.143558 & & -3.143451 & & 0.1190 \\
\hline \multirow{3}{*}{$\Delta \mathrm{BIST}$} & \multirow{3}{*}{-10.99754} & -4.017185 & \multirow{3}{*}{-11.01707} & -4.017185 & \multirow{3}{*}{0.096513} & 0.2160 \\
\hline & & -3.438515 & & -3.438515 & & 0.1460 \\
\hline & & -3.143558 & & -3.143558 & & 0.1190 \\
\hline \multirow{3}{*}{$\Delta \mathrm{GLD}$} & \multirow{3}{*}{-11.67483} & -4.017185 & \multirow{3}{*}{-11.65800} & -4.017185 & \multirow{3}{*}{0.122410} & 0.2160 \\
\hline & & -3.438515 & & -3.438515 & & 0.1460 \\
\hline & & -3.143558 & & -3.143558 & & 0.1190 \\
\hline \multirow{3}{*}{$\triangle$ BRENT } & \multirow{3}{*}{-10.27990} & -4.017185 & \multirow{3}{*}{-10.28694} & -4.017185 & \multirow{3}{*}{0.038085} & 0.2160 \\
\hline & & -3.438515 & & -3.438515 & & 0.1460 \\
\hline & & -3.143558 & & -3.143558 & & 0.1190 \\
\hline
\end{tabular}

Table 4. Results of Unit Root Test (Fixed and with Fixed Trend)

ADF, PP and KPSS unit root tests calculated for models with fixed trend confirmed the findings above. Thus, it is accepted that series are stationary in their first differencing for fixed-trend models.

The fact that series were equally stationary shows that there is probability for BIST 100 index to move parallel along with the gold and oil prices on the long-run. To investigate the existence of this relationship for the long-term, Johansen Co-integration test was applied. To perform this test, the VAR model was estimated by taking optimal delay length (2) determined based on the Schwarz information criterion; and it was tested to see whether there is a structural problem or not. In the second stage, the co-integration test was performed whose results were presented in the Table 5.

\begin{tabular}{|c|c|c|c|c|c|c|c|}
\hline \multicolumn{7}{|c|}{$\begin{array}{l}\text { Sampling: } 2000: 01-2013: 03 \\
\text { Number of observation: } 160 \\
\text { Trend estimation: Linear deterministic trend } \\
\text { Series: BIST GLD BRENT } \\
\text { Delay range: } 1 \text { to } 2 \\
\end{array}$} & \multirow[b]{2}{*}{ Probability* } \\
\hline & Eigen value & $\begin{array}{c}\text { Trace } \\
\text { statistics }\end{array}$ & $\begin{array}{c}0.05 \text { critical } \\
\text { value }\end{array}$ & Prob. & $\begin{array}{l}\text { Maximum Eigen } \\
\text { value statistics }\end{array}$ & $\begin{array}{l}0.05 \text { critical } \\
\text { value }\end{array}$ & \\
\hline None $^{*}$ & 0.151849 & 32.87552 & 29.79707 & 0.0214 & 25.85736 & 21.13162 & 0.0100 \\
\hline \begin{tabular}{|c|} 
At most \\
1
\end{tabular} & 0.043567 & 7.018157 & 15.49471 & 0.5755 & 6.993428 & 14.26460 & 0.4899 \\
\hline \multicolumn{8}{|c|}{\begin{tabular}{|l|l|l|l|l|l|} 
Normalized co-integration equilibrium & BIST $=-0.212365 G L D+1.479564 B R E N T$ \\
\end{tabular}} \\
\hline
\end{tabular}

Table 5. Co-integration Test Results

Trace and maximum eigen value statistics calculated based on the Johansen co-integration test results show that there is one co-integration vector among series at $5 \%$ significance level; in other words, it confirms series act together on the 
long run. From the normalized co-integration equilibrium, one unit increase in oil prices causes 1.479564 unit increase in the BIST 100 index; whereas one unit increase in gold price cause the BIST 100 to decrease by 0.212365 as a negative effect.

\section{Result}

Borsa Istanbul, the capital equity market of Turkey as one of the developing countries, is market that is constantly followed and invested by both local and international investors. Particularly, under the effect of the globalization, as the financial liberalization globally expanding, the Borsa Istanbul has been one of the markets affected from this trend. Due to increasing financial liberalization, the Borsa Istanbul is under the influence of macro economic factors affecting Turkish economy, other stock markets in both developing and developed countries, oil prices, currency rates, gold prices etc. as well.

The present study investigates the effects of oil and gold prices on BIST 100 index in terms of econometric dimension. For this purpose, monthly data obtained from the R.T. Central Bank Electronic Data Distribution System (EVDS) and the Energy Information Administration regarding the period of 2000:01-2013:04 were exploited. To determine the relationships between the BIST 100 index and gold the index and the oil prices, at first, stationary characteristic of series was investigated through unit root tests (ADF-PP-KPSS); then through the Johansen Cointegration test, it was checked whether they were co-integrated or not.

The Johansen co-integration test results regarding series that are stationary in their first difference, show that the BIST 100 index, oil prices and gold prices present movement together on the long term. These results support the other findings in the literature which exhibit that there is relationship between stock prices and international oil and gold prices. In this sense, it was revealed that investors following stock market index are required to take variations in oil and gold prices into consideration beside the other factors. There is positive relationship between oil prices and the BIST 100 index whereas there is negative relationship between gold prices and the BIST 100 index. In other words, when oil prices increase, the BIST 100 index also increases; and when gold prices increase, the BIST 100 index accordingly decreases. From these relationships, it can be concluded that increase in the oil prices indicates the growth in the global economies; and gold prices affect the BIST 100 index adversely since it constitutes an alternative investment mean. That's to say, the investor who shorts on the BIST prefers gold as an investment. This clearly exhibits that the characteristic of gold as a safe-harbor for investors is still prevailing.

\section{References}

Albeni, M. and Demir, Y. (2005). "Makroekonomik Göstergelerin Mali Sektör Hisse Senedi Fiyatlarına Etkisi (IMKB Uygulamalı), Muğla Üniversitesi SBE Dergisi, Bahar, Sayl: 14.

Chen S.S. (2009). "Do Higher Oil Prices Push the Stock Market into Bear Territory?", Energy Economics, doi:10.1016/j.eneco. 2009.08.18

El-Sharif I., Dick Brown, Bruce Burton, Bill Nixon ve alex Russell (2005). "Evidence on the Nature and Extent of the Relationship Between Oil Prices and Equity Values in the UK", Energy Economics, Volume 27, s.819-830

Faff R. W. ve T.J. Brailsford (1999). "Oil Price Risk and Australian Stock Market", Journal of Energy Finance and Development, Volume 4, s.69-87

Henriquesi I. and P. Sadorsky (2008). "Oil Prices and the Stock Prices of Alternative Energy Companies", Energy Economics, Volume 30, s.998-1010

Karan, M. B., (2001), Yatırım Analizi ve Portföy Yönetimi, Gazi Kitapevi, Ankara.

Nandha, M. and Singh, H. (2011). "Short-run and long-run oil price sensitivity of Chinese stocks", Corporate Ownership and Control [P], vol 8, issue 2, Virtus Interpress, Sumy Ukraine, pp. 163-169.

Park, J. ve R. A. Ratti (2008). "Oil Price Shocks and Stock Markets in the U.S. and 13 European Countries", Energy Economics, Volume 30, s.2587-2608

Regnier E. (2007). "Oil and Energy Price Volatility", Energy Economics, Volume 29, s.405-427

Sadorsky P. (1999). "Oil Price Shocks and Stock Market Activity", Energy Economics, Volume 21, s.449-469

Sadorsky P. (2001): "Risk Factors in Stock Returns of Canadian Oil and Gas Companies", Energy Economics, Volume 23, s.17-28

Soytaş, U. ve A. Oran (2008). "Dünya Petrol Fiyatlarındaki Değişim IMKB Elektrik Endeksine Nasıl Yansıyor?", 12. Ulusal Finans Sempozyumu, Enerji Yatıımlarının Finansmanı ve Enerji Verimliği", 22-25 Ekim, Kayseri, s.216-222

Tully, E. and Lucey, B. M., (2007). "A Power GARCH Examination of the Gold Market", Research in International Business and Finance, Sayl: 21. 